\title{
OPTIMASI JUMLAH TENAGA KERJA BERDASARKAN WAKTU STANDARD
}

\author{
Erwin Sitorus \\ Nurhikmah Alfath \\ Jl. Almamater, Padang Bulan, Medan, Sumatera Utara 20155 \\ erwin_birosdmusu@yahoo.com /081264350371 \\ nurhikmahalfath1@gmail.com
}

\begin{abstract}
The most important components in the company are human resources. The use of human resources is not optimal it may cause losses by companies and labor. If the amount of labor is too little, it will cause the buildup at the work station. If the labor too much, it will cause losses due to waste. In this company, the process of producing cigarette paper is divided into three main phases, namely preparation stage, the process of making paper and the finishing stages. The process of producing activities cigarette paper needs human resources optimally. The problems that arise during production process activities are the use of human resources that are not optimal, resulting in the shortage of labor and labor surplus work that is working on the work that is stacking. This study was conducted to determine when the standard work and can provide a good decision in the optimal amount of labor on the packaging of ream paper products form

. Results resulting from the standard time of each element ie the element wrapping cigarette paper sheet with a standard time of 177.79 seconds, enter the box packaging packaging with the standard time, 119.20 seconds, full box with a standard price of 231.15 seconds and wrap the packaging using plastic with a standard time of 55.31 seconds. The total labor standard packaging process with the method of data as much as 15 people / shift seconds actual workforce of 13 people. Enough amount of labor as much as 2 people.
\end{abstract}

Keywords: Standard Time, Rating Factor, Allowance, Stopwatch Time Study

\section{Pendahuluan}

Perusahaan ini adalah perusahaan swasta yang bergerak dalam bidang industri pembuatan kertas rokok (cigarette paper) dalam bentuk bobbin dan ream. Produk bobbin merupakan kertas rokok dalam bentuk gulungan sedangkan produk ream dalam bentuk lembaran kertas. Perusahaan ini memiliki daerah pemasaran yang luas seperti pulau Sumatera, Pulau Jawa ndan sampai ke luar negeri.

Proses produksi kertas rokok terbagi atas tiga tahapan utama yaitu tahap persiapan, tahap proses pembuatan kertas dan tahap finishing. Tahap proses produksi kertas rokok dimulai dari pembuburan, fourdinier, pressing, embossing, pengeringan I, pemberian zat kimia, pengeringan II, penggulungan kertas,pencetakan logo, pemotongan dan pengemasan.

Kegiatan proses produksi kertas rokok membutuhkan sumber daya manusia yang optimal. Sumber daya manusia merupakan salah satu komponen penting dalam perusahaan. Penggunaan sumber daya manusia yang tidak optimal dapat menimbulkan kerugian oleh perusahaan dan tenaga kerja. Apabila jumlah tenaga kerja terlalu sedikit pada stasiun pengepakan, akan menyebabkan penumpukan di stasiun kerja. Sedangkan kelebihan tenaga kerja dapat menimbulkan kerugian akibat pemborosan.

Sumber daya manusia yang tidak mencukupi saat beban produksi meningkat harus dilakukan penambahan sejumlah tenaga kerja yang menyebabkan bertambahnya biaya produksi. Untuk mengatasi hal tersebut perlu dilakukan pengukuran kerja. Pengukuran kerja bertujuan untuk menentukan waktu standard bagi pekerja dan dari waktu standard ini dapat diketahui jumlah tenaga kerja yang optimal pada suatu perusahaan. 
Permasalahan yang terjadi adalah penggunaan sumber daya manusia yang tidak optimal, sehingga kekurangan tenaga kerja dan kelebihan tenaga kerja mengakibatkan ketidakseimbangan kerja yang mengharuskan pekerja di stasiun lainnya melakukan pekerjaan yang mengalami penumpukan. Untuk mengatasi hal tersebut perlu dilakukan pengukuran kerja. Pengukuran kerja dilakukan dengan menentukan waktu standar di bagian pengepakan yang dilakukan oleh operator sehingga diperoleh tenaga kerja yang optimal.

Penelitian sebelumnya dilakukan oleh Dyah (2012) di salah satu IKM batik di Kampoeng Batik Laweyan, Surakarta untuk menentukan waktu baku dan jumlah tenaga kerja optimal pada setiap tahapan proses. Dewi agustini (2010) juga melakukan penelitian di salah satu perusahaan botol yang ada di Semarang. Penelitian dilakukan untuk mengetahui waktu baku dan jumlah tenaga kerja optimal dan efektif yang dibutuhkan bagian tersebut sesuai perhitungan waktu baku menggunakan metode work sampling. Hasil yang diperoleh dalam berupa proses produksi botol 1 liter di PT. C. sudah terstruktur dengan baik dan pada prosesnya menggunakan peralatan semi otomatis. Selain itu, Ridwan juga melakukan penelitian dengan menganalisa beban kerja dan jumlah tenaga kerja menggunakan metode Work Load Analysis (WLA). Berdasarkan penelitian-penelitian sebelumnya, penelitian bertujuan untuk mengetahui jumlah tenaga kerja yang optimal berdasarkan waktu standard pada bagian pengepakan di PT. XYZ.

\section{Bahan dan Metode Penelitian}

Penelitian ini merupakan penelitian kuantitatif yang bertujuan untuk mengetahui jumlah optimal tenaga kerja yang dibutuhkan berdasarkan waktu standar. Penelitian dilakukan pada pengepakan produk kertas rokok dalam bentuk ream yang di packing dengan karton dan plastik pembungkus. Proses pengepakan pada hasil kertas rokok dalam bentuk ream adalah membungkus lembaran kertas rokok, menyiapkan kemasan kertas rokok, dan membungkus kemasan menggunakan plastik dengan mesin cycklope. Penelitian dilakukan secara langsung dengan menerapkan stopwatch time study dalam pengukuran waktu. Pengukuran waktu kerja pada dasarnya merupakan suatu usaha untuk menentukan lamanya waktu kerja yang diperlukan oleh seorang operator untuk menyelesaikan suatu pekerjaan (Niebel, 1988). Pengamatan dilakukan sebanyak 10 kali dimana 13 tenaga kerja di bagian pengepakan menjadi populasi penelitian.

Setelah dilakukan pengumpulan data melalui pengamatan secara langsung, kemudian dilakukan tahapan-tahapan penyelesaian masalah antara lain:

1.Menguraikan elemen gerakan kegiatan pengepakan.

2.Menentukan allowance dan rating factor kerja operator

Allowance dimaksudkan untuk memberikan kesempatan kepada operator untuk melakukan hal-hal yang harus dilakukannya, sehingga waktu baku yang diperoleh dapat dikatakan data waktu kerja yang lengkap dan mewakili sistem kerja yang diamati. Kelonggaran yang diberikan antara lain:

a.kelonggaran untuk kebutuhan pribadi

b.kelonggaran untuk menghilangkan rasa lelah (fatique)

c.kelonggaran untuk hal-hal yang tidak dapat dihindarkan

Rating factor merupakan teknik untuk menyamakan waktu hasil observasi terhadap seorang operator dalam menyelesaikan suatu pekerjaan dengan waktu yang diperlukan oleh operator normal dalam menyelesaikan pekerjaan tersebut (Niebel, 1988). Besarnya harga faktor penyesuaian (p) memiliki tiga batasan, yaitu (Sutalaksana, 2001):

a.p $>1$ bila pengukur berpendapat bahwa operator bekerja di atas normal (terlalu cepat)

b.p $<1$ bila pengukur berpendapat bahwa operator bekerja di bawah normal (terlalu lambat) 
c.p $=1$ bila pengukur berpendapat bahwa operator bekerja dengan wajar

Metode yang digunakan untuk menentukan rating factor dalam penelitian ini adalah Westinghouse factor.

3.Perhitungan waktu normal dan waktu standar untuk menyelesaikan pengepakan kertas rokok bentuk ream.

Waktu normal merupakan waktu kerja yang telah mempertimbangkan faktor penyesuaian, yaitu waktu siklus rata-rata dikalikan dengan faktor prnyesuaian.

Waktu normal $=$ Ws $x$ Rf

Sedangkan perhitungan waktu standar dilakukan dengan menggunakan rumus (Wignjosoebroto, 2003):

Waktu standar $=$ Wn $\times \frac{1}{1-\text { Allowance }}$

4.Penentuan jumlah tenaga kerja berdasarkan waktu standar yang diproleh.

\section{III.Analisis dan Pembahasan}

\section{A. Perhitungan waktu normal}

Waktu normal merupakan waktu kerja yang telah mempertimbangkan faktor penyesuaian, yaitu waktu siklus rata-rata dikalikan dengan rating factor. Nilai rating factor dan allowance yang diperoleh dapat dilihat pada Tabel 1.

Tabel 1. Rating Factor \& Allowence Tiap

Elemen

\begin{tabular}{|c|l|c|c|}
\hline No & \multicolumn{1}{|c|}{ Kegiatan } & Rf & All \\
\hline 1 & $\begin{array}{l}\text { Membungkus lembaran } \\
\text { kertas rokok }\end{array}$ & 1.13 & 0.16 \\
\hline 2 & $\begin{array}{l}\text { Memasukkan kemasan } \\
\text { kedalam kotak kemasan }\end{array}$ & 1.13 & 0.14 \\
\hline 3 & $\begin{array}{l}\text { Meletakkan kotak kemasan } \\
\text { pada pallet }\end{array}$ & 1.16 & 0.14 \\
\hline 4 & $\begin{array}{l}\text { Membungkus kemasan } \\
\text { menggunakan plastik }\end{array}$ & 1.07 & 0.14 \\
\hline
\end{tabular}

Berdasarkan tabel diatas, dapat dihitung waktu normal untuk setiap kegiatan dimana pada kegiatan membungkus lembaran kertas rokok diperoleh waktu normal sebesar 149,35.

\section{B. Perhitungan waktu standar}

Waktu standar pekerja membungkus lembaran kertas rokok adalah sebesar 177,79 detik. Rangkuman hasil perhitungan dapat dilihat pada Tabel 2.
Tabel 2. Rangkuman Hasil Perhitungan Wn dan Wb untuk Setiap Elemen Kerja

\begin{tabular}{|l|c|c|c|c|c|}
\hline \multicolumn{1}{|c|}{ Kegiatan } & Ws & $\mathrm{Rf}$ & All & $\mathrm{Wn}$ & $\mathrm{W}_{\text {standar }}$ \\
\hline $\begin{array}{l}\text { Membungkus } \\
\text { lembaran }\end{array}$ & 132,17 & 1,13 & 0,16 & 149,35 & 177,79 \\
\hline $\begin{array}{l}\text { Memasukkan } \\
\text { kemasan } \\
\text { kedalam kotak }\end{array}$ & 90,72 & 1,1 & 0,14 & 102,51 & 119,20 \\
\hline $\begin{array}{l}\text { Meletakkan } \\
\text { kotak pada } \\
\text { pallet }\end{array}$ & 171,37 & 1,16 & 0,14 & 198,79 & 231,15 \\
\hline $\begin{array}{l}\text { Membungkus } \\
\text { kemasan } \\
\text { dengan plastik }\end{array}$ & 44,45 & 1,07 & 0,14 & 47,56 & 55,31 \\
\hline
\end{tabular}

Allowance yang terdapat pada kegiatan persiapan pengepakan termasuk allowance yang tinggi dikarenakan keadaan temperature yang cukup panas. Sedangkan rating factor yang dihasilkan pekerja yang masih wajar untuk dilakukan. Dikarenakan sebagian dari pekerja sudah cukup lama bekerja di perusahaan ini sehingga sudah terbiasa dalam melakukan gerakan kerja.

\section{Penentuan jumlah tenaga kerja}

Banyaknya jumlah kertas rokok yang diproduksi dalam bentuk ream per shift adalah 1.560 bungkus. Dalam 1 kotak memuat 10 bungkus, Jadi, dalam sehari jumlah packing karton adalah sebanyak 156 kotak. Jam kerja efektif adalah 8 jam/orang dengan jam istirahat 1 jam/orang. Jumlah tenaga kerja pada saat ini adalah sebanyak 13 orang, dengan pembagian kerja:

1. Membungkus lembaran kertas rokok sebanyak 9 orang.

2. Memasukkan kemasan kedalam kotak kemasan 1 orang.

3. Meletakkan kotak kemasan pada pallet 2 orang.

4. Membungkus

kemasan menggunakan plastik 1 orang.

Perhitungan jumlah tenaga kerja untuk setiap kegiatan antara lain sebagai berikut:

1. Membungkus lembaran kertas rokok 
Jam kerja $=8$ jam/orang

Jam istirahat $=1$ jam/orang

$\mathrm{JKE} \quad=8 \mathrm{jam}-1 \mathrm{jam}$ $=7 \mathrm{jam} /$ orang

Beban kerja $=\mathrm{Jlh}$ produksi $/$ hari $\mathrm{x} \mathrm{Wb}$

$=1560 \times 177,79$

$=277352$ detik

Waktu tersedia $=7 \times 3600$ detik

$$
=25200 \text { detik }
$$

Jumlah tenaga kerja:

= beban kerja/waktu yang tersedia

$=277352 / 25200$

$=11.00 \approx 11$ orang per shift

2. Memasukkan kemasan kedalam kotak kemasan Jam kerja $\quad=8$ jam/orang

Jam istirahat $=1$ jam/orang

$\mathrm{JKE}=8 \mathrm{jam}-1 \mathrm{jam}$

$=7 \mathrm{jam} /$ orang

Beban kerja $=\mathrm{Jlh}$ produksi/hari $\mathrm{x} \mathrm{Wb}$

$=1560 / 10 \times 119,20$ $=18595,2$ detik

Waktu tersedia $=7 \times 3600$ detik $=25200$ detik

Jumlah tenaga kerja

$=$ beban $\mathrm{kerja} /$ waktu yang tersedia

$=18595,2 / 25200$

$=0,74 \approx 1$ orang per shift

3. Meletakkan kotak kemasan pada pallet

Jam kerja $=8 \mathrm{jam} /$ orang

Jam istirahat $=1$ jam/orang

$\mathrm{JKE}=8 \mathrm{jam}-1 \mathrm{jam}$ $=7 \mathrm{jam} /$ orang

Beban kerja $=\mathrm{Jlh}$ produksi/hari $\mathrm{x} \mathrm{Wb}$

$$
=1560 / 12 \times 231,1
$$$$
=30049 \text { detik }
$$

Waktu tersedia $=7 \times 3600$ detik

$$
=25200 \text { detik }
$$

Jumlah tenaga kerja

$=$ beban kerja/waktu yang tersedia

$=30049 / 25200$

$=1,19 \approx 2$ orang per shift

4. Membungkus kemasan menggunakan plastik

Jam kerja $=8$ jam/orang

Jam istirahat $=1$ jam/orang

$\mathrm{JKE} \quad=8 \mathrm{jam}-1 \mathrm{jam}$

$=7 \mathrm{jam} /$ orang

Beban kerja $=\mathrm{Jlh}$ produksi/hari $\mathrm{x} \mathrm{Wb}$

$=1560 / 13 \times 55,31$

$=6637$ detik
Waktu tersedia $=7 \times 3600$ detik $=25200$ detik

Jumlah tenaga kerja

= beban kerja/waktu yang tersedia

$=6637 / 25200$

$=0.26 \approx 1$ orang per shift

Dari hasil perhitungan tenaga kerja berdasarkan waktu standar, dapat diperoleh jumlah tenaga kerja pada bagian packing dapat dilihat pada Tabel 3.

Tabel 3. Jumlah Tenaga Kerja Usulan

\begin{tabular}{|l|l|c|}
\hline No & \multicolumn{1}{|c|}{ Kegiatan } & $\begin{array}{c}\text { Jumlah } \\
\text { Tenaga Kerja }\end{array}$ \\
\hline 1 & $\begin{array}{l}\text { Membungkus lembaran } \\
\text { kertas rokok }\end{array}$ & 11 \\
\hline 2 & $\begin{array}{l}\text { Memasukkan kemasan } \\
\text { kedalam kotak kemasan }\end{array}$ & 1 \\
\hline 3 & $\begin{array}{l}\text { Meletakkan kotak } \\
\text { kemasan pada pallet }\end{array}$ & 1 \\
\hline 4 & $\begin{array}{l}\text { Membungkus kemasan } \\
\text { menggunakan plastik }\end{array}$ \\
\hline
\end{tabular}

Berdasarkan perbandingan jumlah tenaga kerja dengan menggunakan waktu standar diperoleh jumlah tenaga kerja sebanyak 15 orang, sedangkan pada kondisi awal terdapat 13 tenaga kerja. Maka diperoleh bahwa pada bagian pengepakan terdapat kekurangan tenaga kerja sebanyak 2 orang, kekurangan tenaga kerja tersebut terdapat pada kegiatan membungkus lembaran kertas rokok. Kegiatan membungkus lembaran kertas rokok membutuhkan jumlah tenaga kerja yang paling banyak karena kegiatan ini merupakan kegiatan awal pada proses pengepakan yang nantinya akan menentukan kecepatan pengerjaan di kegiatan berikutnya.

Berdasarkan perhitungan jumlah tenaga kerja secara teori adanya kekurangan jumlah tenaga kerja pada bagian membungkus lembaran kertas rokok. Secara aktual jumlah tenaga kerja yang terdapat pada bagian membungkus lembaran kertas rokok sebanyak 9 orang, namun secara teoritis jumlah tenaga kerja yang seharusnya ada di bagian ini yaitu sebanyak 11 orang. Adanya ketidakseimbangan antara jumlah tenaga kerja di bagian ini karena proses 
pemeriksaan/pengecekan produk kertas masih secara manual sehingga menyebabkan terjadinya penumpukan sebelum dikemas ke dalam kotak.

\section{Kesimpulan dan Saran}

Berdasarkan perhitungan jumlah tenaga kerja secara teori adanya kekurangan jumlah tenaga kerja pada bagian membungkus lembaran kertas rokok. Adanya ketidakseimbangan antara jumlah tenaga kerja di bagian ini karena proses pemeriksaan/pengecekan produk kertas masih secara manual sehingga menyebabkan terjadinya penumpukan sebelum dikemas ke dalam kotak. Secara aktual jumlah tenaga kerja yang terdapat pada bagian membungkus lembaran kertas rokok sebanyak 9 orang, namun secara teoritis jumlah tenaga kerja yang seharusnya ada di bagian ini yaitu sebanyak 11 orang.

Dalam mengatasi permasalahan optimasi tenaga kerja, perlu dilakukan pelatihan keterampilan secara berkala kepada operator pengepakan dari pihak perusahaan sehingga meningkatkan gerakan yang terencana dan koordinasi gerakan tangan dan pikiran yang baik.

\section{Daftar Pustaka}

1. Niebel, B. W. (1988). Motion and Time Study. Irwin, Honewood, Illinois.

2. Dyah Ika Rinawati, Diana Puspitasari, dkk, (2012), Penentuan Waktu Standar Dan Jumlah Tenaga Kerja Optimal Pada Produksi Batik Cap (Studi Kasus: Ikm Batik Saud Effendy, Laweyan), Jurnal Teknik Industri Undip Vol. VII, No. 3, Semarang.

3. Dewi Agustini Santoso, Agus Supriyadi, (2010), Perhitungan Waktu Baku dengan Metode Work Sampling untuk Menentukan Jumlah Tenaga Kerja Optimal, Prosiding Seminar Nasional Sains dan Teknologi, Semarang.

4. Ridwan, Arif, (2012), Analisa Beban Kerja dan Jumlah Tenaga Kerja yang Optimal pada Bagian Produksi dengan Pendekatan Metode Work Load Analysis (WLA) di PT.Surabaya
Perdana Rotopack, Jurnal Teknik Industri UPN, Surabaya.

5. Sutalaksana , Iftikar, dkk., (2006), Teknik Perancangan Sistem Kerja, ITB, Bandung.

6. Wignjosoebroto, Sritomo., (2003), Tataletak Pabrik dan Pemindahan Bahan, Guna Widya, Surabaya. 